University of Nebraska - Lincoln

DigitalCommons@University of Nebraska - Lincoln

Faculty Publications from the Harold W. Manter

Laboratory of Parasitology

Parasitology, Harold W. Manter Laboratory of

8-2003

Whallwachsia illuminata n. gen., n. sp. (Trematoda: Digenea:

Plagiorchiformes: Prosthogonimidae) in the Steely-Vented

Hummingbird Amazilia saucerrottei (Aves: Apodiformes:

Trochilidae) and the Yellow-Olive Flycatcher Tolmomyias

sulphurescens (Aves: Passeriformes: Tyraninidae) from the Área

de Conservación Guanacaste, Guanacaste, Costa Rica

\author{
David Zamparo \\ University of Toronto \\ Daniel R. Brooks \\ University of Toronto,dnlbrooks@gmail.com \\ Douglas Causey \\ University of Alaska Anchorage, dcausey@uaa.alaska.edu \\ Follow this and additional works at: https://digitalcommons.unl.edu/parasitologyfacpubs \\ Part of the Parasitology Commons
}

Zamparo, David; Brooks, Daniel R.; and Causey, Douglas, "Whallwachsia illuminata n. gen., n. sp. (Trematoda: Digenea: Plagiorchiformes: Prosthogonimidae) in the Steely-Vented Hummingbird Amazilia saucerrottei (Aves: Apodiformes: Trochilidae) and the Yellow-Olive Flycatcher Tolmomyias sulphurescens (Aves: Passeriformes: Tyraninidae) from the Área de Conservación Guanacaste, Guanacaste, Costa Rica" (2003). Faculty Publications from the Harold W. Manter Laboratory of Parasitology. 235.

https://digitalcommons.unl.edu/parasitologyfacpubs/235

This Article is brought to you for free and open access by the Parasitology, Harold W. Manter Laboratory of at DigitalCommons@University of Nebraska - Lincoln. It has been accepted for inclusion in Faculty Publications from the Harold W. Manter Laboratory of Parasitology by an authorized administrator of DigitalCommons@University of Nebraska - Lincoln. 


\title{
WHALLWACHSIA ILLUMINATA N. GEN., N. SP. (TREMATODA: DIGENEA: PLAGIORCHIFORMES: PROSTHOGONIMIDAE) IN THE STEELY-VENTED HUMMINGBIRD AMAZILIA SAUCERROTTEI (AVES: APODIFORMES: TROCHILIDAE) AND THE YELLOW-OLIVE FLYCATCHER TOLMOMYIAS SULPHURESCENS (AVES: PASSERIFORMES: TYRANINIDAE) FROM THE AREA DE CONSERVACIÓN GUANACASTE, GUANACASTE, COSTA RICA
}

\author{
David Zamparo, Daniel R. Brooks, and Douglas Causey \\ Department of Zoology, University of Toronto, Toronto, Ontario M5S 3G5, Canada. e-mail: zamparo@zoo.utoronto.ca
}

\begin{abstract}
A new species of digenean found in the intestines of the steely-vented hummingbird Amazilia saucerrottei and the yellow-olive flycatcher Tolmomyias sulphurescens from the Area de Conservación Guanacaste, Guanacaste, Costa Rica, resembles members of the Prosthogonimidae in having a highly lobate ovary; an elongate cirrus sac containing the cirrus, pars prostatica, and internal seminal vesicle; no external seminal vesicle; 2 fields of extracecal vitelline follicles restricted to the area between the intestinal bifurcation and testes; and uterine loops occupying all available space in the hind body. The new species differs from all other members of the family in having genital pores opening laterally to the cecum, immediately anterior to the acetabular level, and markedly oblique rather than symmetrical testes. Consequently, we propose the new genus Whallwachsia for the species. Preliminary phylogenetic assessment suggests that the species is the sister group of all other prosthogonimids.
\end{abstract}

The goals of modern biodiversity inventories set out in initiatives such as Systematics Agenda 2000, the Global Taxonomy Initiative, and the All-Species Foundation have been presented previously to parasitologists (Brooks, 2000, 2003; Brooks and Hoberg, 2000, 2001; Brooks et al., 2000; Brooks and McLennan, 2002; Hoberg, 2002; Hoberg et al., 2002; LeónRégàgnon, 2003; Pérez Ponce de León, 2003). In short, taxonomists are called upon to complete the world's census of species as quickly as possible, place those species and all that is known of their natural history in predictive (i.e., phylogenetic) classifications, and make that information freely available electronically.

The parasite fauna of tropical vertebrates is not well known. Beginning in 1996, the Area de Conservación Guanacaste (hereafter referred to as the ACG) (http://www.acguanacaste.ac.cr) in northwestern Costa Rica has supported an effort to perform an inventory of all eukaryotic parasites of the 940 species of vertebrates living within the ACG (http://brooksweb.zoo.utoronto. $\mathrm{ca} / \mathrm{index} \cdot \mathrm{html}$ ). In each report of results of this inventory, we will strive, insofar as our data permit, to contribute 3 types of information (based on as much information as possible): (1) the names of each species, (2) their phylogenetic relationships, and (3) their natural history, including abiotic and biotic aspects of the environments in which they are found. We hasten to add that, because the primary goal is completing the world's census as rapidly as possible, our contributions with respect to both phylogenetic and natural history information will not be exhaustive. In some cases, we will be able to describe species on the basis of both morphological and molecular data (e.g., León-Régàgnon et al., 2001), but in many cases we will need to describe morphospecies first to facilitate molecular studies. Our contributions to phylogenetic understanding, when possible, will minimally comprise summarizing the characters used to distinguish each new species from other similar species in the form of a cladogram. In some cases, we will be able to integrate such infor-

Received 9 October 2002; revised 5 March 2003; accepted 5 March 2003.

* Museum of Comparative Zoology, Harvard University, Cambridge, Massachusetts. mation into existing phylogenetic hypotheses. In all cases, there will still be a great need for comprehensive phylogenetic revisions and intensive ecological, population biological, and life cycle studies. Nonetheless, we hope to provide more information than simply a minimal species description.

During the course of this inventory, we will be reporting new species, whose attributes will not nest comfortably into existing classifications, especially those not based on phylogenetic reasoning. In some cases, this will make existing taxonomic keys and diagnoses insufficient. This is an unavoidable consequence of progress in taxonomic work. We noted above that 1 of the goals of modern biodiversity inventories is to make this information freely available electronically (i.e., through the internet). There is no better illustration of this need than realizing that taxonomic keys available only in print form are not capable of being updated in a timely enough manner to keep up with current knowledge.

Herein, we describe a new species of digenean parasitizing some birds in the ACG, for which we propose a new genus.

\section{MATERIALS AND METHODS}

Worms were collected alive from recently killed birds, killed and fixed by shaking in hot formalin, and then stored in $70 \%$ ethanol. Specimens were stained with Mayer's hematoxylin, dehydrated, and mounted in Canada balsam. All measurements are in micrometers unless otherwise stated. First series of values stated is the range, and the values in parentheses are the means of the measurements. All figures were drawn with the aid of a drawing tube.

\section{DESCRIPTION}

Whallwachsia $\mathrm{n}$. gen.

Diagnosis: Digenea: Plagiorchiformes: Prosthogonimidae. Body elongate, spinose. Oral sucker subterminal. Prepharynx short. Pharynx present. Esophagus short. Ceca terminating well short of posterior end of body. Ventral sucker in anterior half of body. Testes, intercecal, diagonal (oblique), in midbody. Cirrus sac elongate, containing cirrus, pars prostatica, and internal seminal vesicle; external seminal vesicle lacking. Genital pores opening together, posterolateral to sinistral cecum, opening slightly anterior to acetabular level. Ovary postacetabular, intercecal, dextral, lobate. Mehlis gland and seminal receptacle postovarian. Laurer canal absent. Vitellarium follicular, in extracecal rows 
restricted to the area between the intestinal bifurcation and testes. Uterus occupying all available space in hind body. Excretory vesicle I-shaped. Excretory pore subterminal, ventral. Type species Whallwachsia illuminata $\mathrm{n}$. sp.

\section{Whallwachsia illuminata $\mathrm{n} . \mathbf{s p}$.}

$$
\text { (Figs. 1-3) }
$$

Description (based on 30 mature ovigerous specimens): Body elongate, 2.14-3.68 (2.96) mm long, 0.68-1.13 (0.89) mm wide. Maximum width at either level of anterior testis or immediately posterior to posterior testis. Tegument spinose, densely covered with small spines. Oral sucker subterminal, nearly round, 171-236 (201) long, 171-247 (198) wide. Oral sucker width:pharynx width ratio 1:0.39-0.56 (1:0.48). Prepharynx short. Pharynx 84-118 (103) long, 76-114 (95) wide. Esophagus 30-125 (54) long. Intestinal bifurcation 10-18\% (13\%) of total body length (TBL) from anterior end. Ceca long and narrow, occupying 79-90\% (84\%) of TBL. Forebody 19-29\% (23\%) TBL from anterior end. Ventral sucker 160-247 (216) long, 163-247 (209) wide. Oral sucker width:ventral sucker width ratio 1:0.89-1.31 (1:1.1). Testes, intercecal, oblique, not abutting, anterior testis sinistral $42-57 \%$ (46\%) of TBL from anterior end, 228-422 (349) long, 171-511 (382) wide; posterior testis dextral, 54-68\% (59\%) of TBL from anterior end, 228-607 (386) long, 190-510 (427) wide. Genital pore lateral or ventral to sinistral cecum, $17-30 \%(22 \%)$ of TBL from anterior end. Cirrus sac dorsal to ventral sucker, 506-1,013 (766) long (Fig. 2). Ejaculatory portion of cirrus 314-623 (472) long, 71-142 (96) wide containing prostatic cells. Internal seminal vesicle portion of cirrus sac 152-506 (293) long by 76-162 (117) wide. Ovary lobate, dextral, between ventral sucker and anterior testis, 118-304 (205) long by 163-418 (287) wide. Mehlis gland posterior to ovary, dorsal to seminal receptacle (Fig. 3). Ascending uterine loops intercecal, transverse uterine loops extracecal posterior to posterior testis. Vitelline fields extending from ventral sucker to posterior end of anterior testis, occasionally overlapping ceca ventrally, dextral field longer than sinistral, extending from 16-39\% (26\%) TBL from anterior end to 49-67\% (56\%) TBL from anterior end. Sinistral vitelline field extending from 18.8-34.3 (25.7\%) TBL from anterior end to $46-64 \%$ (51\%) TBL from anterior end. Metraterm present, 110-300 (261) long. Excretory bladder I-shaped, long, and narrow. Excretory pore subterminal, ventral. Eggs light yellow to dark brown in color, 18-22 (20) long by 9-13 (11) wide.

\section{Taxonomic summary}

Type host: Amazilia saucerrottei (Aves: Apodiformes: Trochilidae), steely-vented hummingbird.

Other hosts: Tolmomyias sulphurescens (Aves: Passeriformes: Tyrannidae), yellow-olive flycatcher.

Prevalence, intensity, and site of infection: Amazilia saucerrottei (4 of $23 ; 1,1,1$, and 7 worms; intestine); T. sulphurescens ( 1 of 10; 20 worms; bile duct).

Type locality: Cafetal, ACG $\left(10^{\circ} 51^{\prime} 13^{\prime \prime} \mathrm{N}, 85^{\circ} 36^{\prime} 32^{\prime \prime} \mathrm{W} ; 320 \mathrm{~m}\right.$ elevation).

Other localities: Main entrance to Santa Rosa, ACG $\left(10^{\circ} 50^{\prime} 42^{\prime \prime} \mathrm{N}\right.$, $85^{\circ} 36^{\prime} 48^{\prime \prime} \mathrm{W} ; 263 \mathrm{~m}$ elevation); Parcela principe, ACG $\left(10^{\circ} 51^{\prime} 13^{\prime \prime} \mathrm{N}\right.$, $85^{\circ} 56^{\prime} 32^{\prime \prime} \mathrm{W} ; 320 \mathrm{~m}$ elevation); and Estacion San Gerardo, ACG $\left(10^{\circ} 52^{\prime} 50^{\prime \prime} \mathrm{N}, 85^{\circ} 23^{\prime} 21^{\prime \prime} \mathrm{W} ; 605 \mathrm{~m}\right.$ elevation).

Type material: Holotype, USNPC no. 93187; paratypes, USNPC nos. 93188, 93189.

Etymology: The new genus is named after Dr. Winnie Hallwachs, Scientific Adviser, ACG, in recognition of her many years of dedication to the preservation of the world's biodiversity, particularly on behalf of the ACG. The specific epithet recognizes the insights into digenean phylogeny provided by the species.

\section{Remarks}

Brooks et al. $(1985,1989)$ presented the first strictly phylogenetic systematic analysis of digenean families, based on the suite of traits commonly used in traditional classifications. That study supported most previous taxonomic studies, suggesting a clade usually called the Microphalloidea, comprising a clade of the Prosthogonimidae + Lecithodendriidae, with the Microphallidae as their sister group. Brooks et al. (1985, 1989) suggested 2 autapomorphies for the Prosthogonimidae, genital pores at the anterior end of the body and "follicular", or lobate, ovaries. Angel (1973) recognized 8 prosthogonimid genera: Cephalotrema Baer, 1943, Praeuterogonimus Sudarikov and Nguyen Tchi Le, 1968, and Coelomotrema Angel, 1970 in mammalian hosts; and Ophthalmogonimus Oshmarin in Skrjabin, 1962, Prosthogonimus Lühe, 1899, Mediogonimus Woodhead and Malewitz, 1936, Mawsonotrema Angel, 1973, and Cylindrotrema Angel, 1973 in avian hosts. She also synonymized Schistogonimus with Prosthogonimus following the experimental work of Krasnolobova (1969). Of the genera recognized by Angel (1973), members of Cephalotrema and Coelomotrema differ from all other prosthogonimids in possessing a spherical ovary with smooth margins. In this regard, it is noteworthy that Baer (1943) originally placed Cephalotrema in the Lecithodendriidae. We concur with his original assessment and consider Coelomotrema a lecithodendriid as well.

Recent analyses, based on partial sequences of lsrDNA and $28 \mathrm{~S}$ rDNA (Tkach et al., 2000, 2001) from a small number of species of digeneans, have corroborated the hypothesis that Microphalloidea is a clade but have also suggested that the Lecithodendriidae sensu Brooks et al. $(1985,1989)$ is paraphyletic, with the Prosthogonimidae being a member of a clade containing the paraphyletic Pleurogenidae and the Allassogonoporidae (=Pleurogeninae and Allassogonoporidae within the Lecithodendriidae of many authors, e.g., Yamaguti [1971] and Brooks et al. [1985, 1989]) and the rest of the Lecithodendriidae being the sister group of the Microphallidae. To date, no effort has been made to expand the morphological database or to combine the molecular and morphological data, and there has been no comprehensive phylogenetic analysis within the superfamily.

The new species exhibits the postacetabular, highly lobed ovary characteristic of prosthogonimids but differs from all other prosthogonimids in having a genital pore opening anterolaterally to the ventral sucker rather than at the anterior end of the body. In the majority of microphalloids, the posterior end of the cirrus sac lies in the vicinity of the ventral sucker, and the cirrus sac itself is elongate, containing a voluminous internal seminal vesicle and elongate pars prostatica and cirrus. The genital pore in most species is anterior or anterolateral to the ventral sucker and intercecal. In pleurogenids and allassogonoporids, the genital pore is lateral to the ventral sucker, ranging from ventral to the ceca to opening on the lateral margin of the body. If prosthogonimids are more closely related to pleurogenids and allassogonoporids than to other microphalloids (Tkach et al., 2000, 2001), the position of the genital pore in the new species is best explained as plesiomorphic, the new species providing evidence of the evolutionary transition from genital pores opening laterally in the common ancestor of the pleurogenids, allassogonoporids, and prosthogonimids, a morphological synapomorphy for the clade recognized previously only by molecular data, to those opening at the anterior end of the body in the other prosthogonimids, a synapomorphy for those species. It thus appears that the new species is the sister group of all other prosthogonimids. The new species also differs from the majority of species of prosthogonimids in possessing an elongate rather than a pear-shaped body and in exhibiting diagonal (oblique) rather than symmetrical testes. In this regard, the new species resembles Prosthogonimus (Prosthogonimus) sp. of Ramadan et al. (1988) parasitizing the house sparrow Passer domesticus niloticus in Egypt, which, however, exhibits a genital pore at the anterior end of the body. We are not certain whether the elongate body form and oblique testes exhibited by the new species are plesiomorphic or apomorphic, relative to the other prosthogonimids; at present, however, we cannot assign the new species to a known genus and thus propose the new genus to accommodate it. In addition, because we have no putative synapomorphy for the new genus, we propose that it be maintained within the Prosthogonimidae and thus emend the family diagnosis to include species with marginal genital pores as well as genital pores at the anterior end of the body.

Figure 4 summarizes the above discussion in the form of a cladogram based on the results presented by Tkach et al. (2001) but modified to include W. illuminata as well as the morphological traits considered by Brooks et al. (1985, 1989; see also Brooks and McLennan, 1993) and the new putative morphological synapomorphies discussed above and below. 


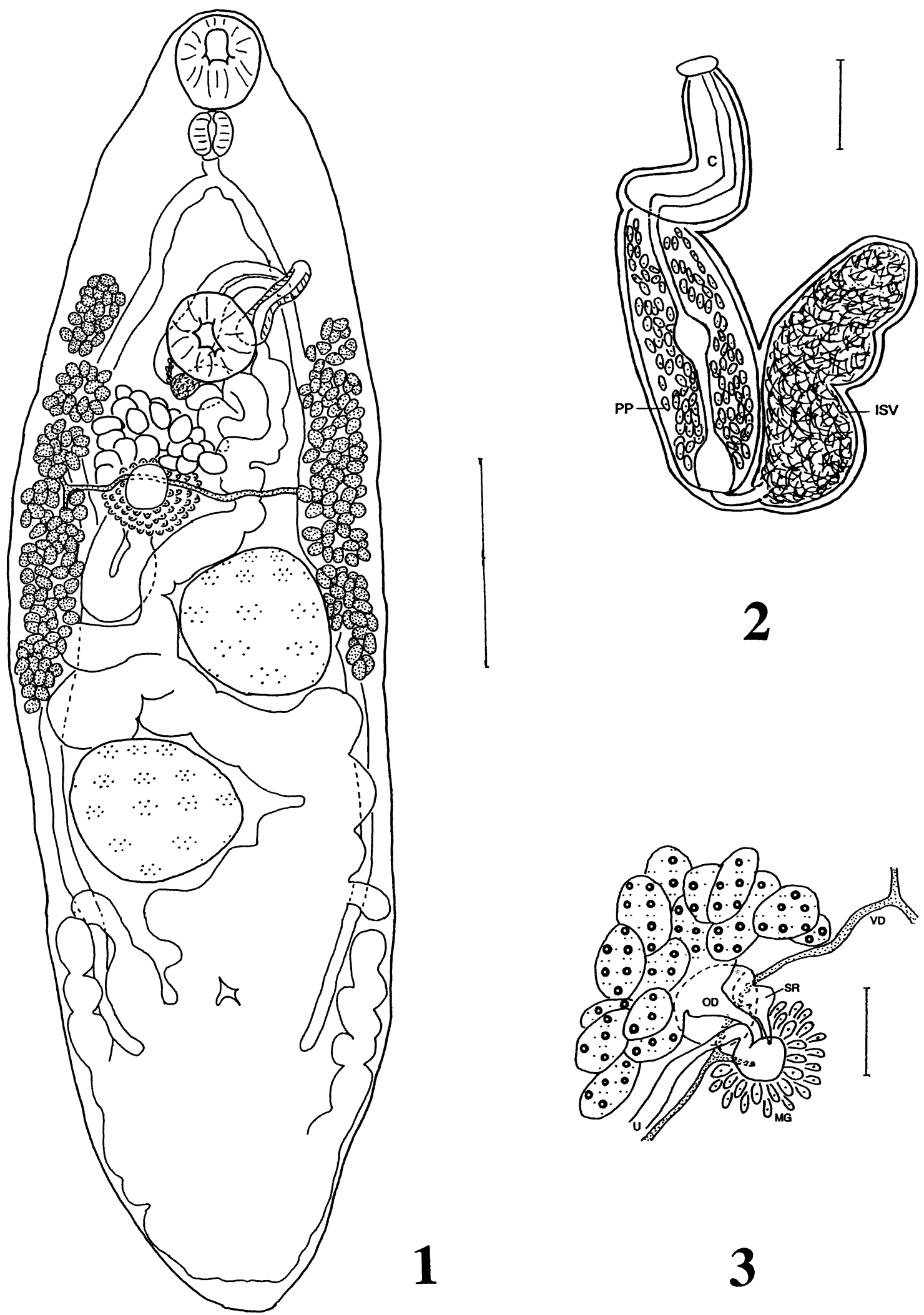

FIGURES 1-3. Whallwachsia illuminata n. gen., n. sp. 1. Ventral view of holotype. Bar $=500 \mu \mathrm{m}$. 2. Male genitalia. ISV $=$ internal seminal vesicle; $\mathrm{PP}=$ pars prostatica; $\mathrm{C}=$ cirrus. $\mathrm{Bar}=100 \mu \mathrm{m}$. 3. Ootype region. $\mathrm{MG}=$ Mehlis gland; $\mathrm{OD}=$ oviduct; $\mathrm{SR}=$ seminal receptacle; $\mathrm{U}=$ uterus; $\mathrm{VD}=$ vitelline duct. $\mathrm{Bar}=100 \mu \mathrm{m}$. 


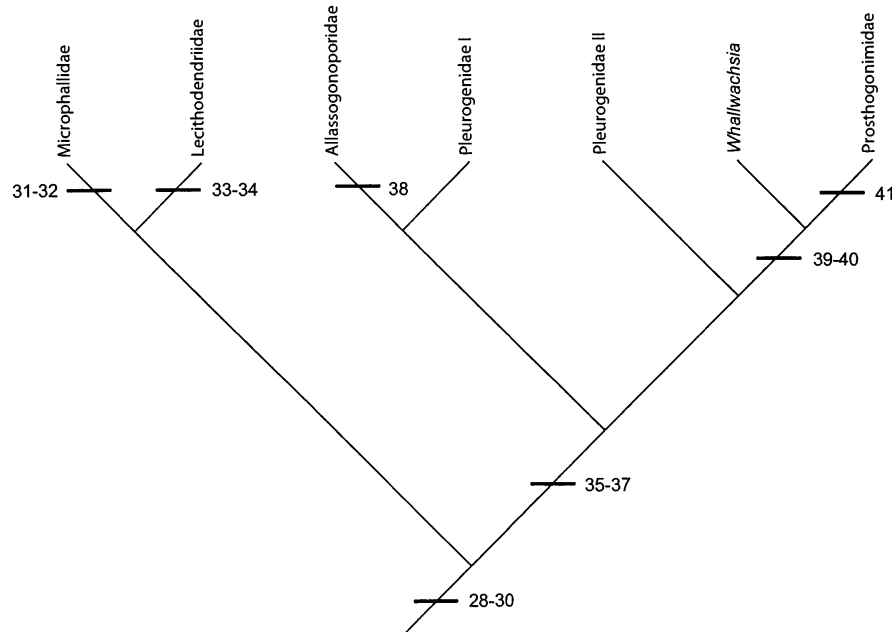

FIGURE 4. Cladogram depicting phylogenetic relationships among selected groups of Microphalloidea (Digenea). The topology of the cladogram is derived from that of Tkach et al. (2001), with the addition of Whallwachsia illuminata. The following morphological synapomorphies support this topology, derived from Brooks et al. (1985, 1989), Brooks and McLennan (1993), and discussion in text: V-shaped excretory vesicles (28); small "daughter sporocysts" with few cercariae (29); extremely small adult bodies (30) prominent and highly modified terminal genitalia, including muscularized genital atrium (31); "ubiquita" cercariae (32); vitelline follicles bunched in "shoulder" region (33); "virgulate" cercariae (34); genital pores near the oral sucker (35); secondarily elongate cirrus sacs (36); vitelline follicles bunched in shoulder region (35); virgulate cercariae (36); genital pores anterolateral to ventral sucker (37); genital pores posterolateral to ventral sucker (38); follicular ovaries; (39); vitelline follicles not bunched in shoulder region (40); genital pores at anterior end of body (41). Numbers refer to the on-line phylogenetic database at http://brooksweb.zoo. utoronto.ca/index.html.

\section{DISCUSSION}

Optimizing morphological characters, summarized by Brooks and McLennan (1993) and presented in the above discussion, onto the cladogram derived from the molecular data indicates that the morphological data provide incomplete, rather than conflicting, hypotheses of relationships with respect to the molecular data.The discovery of $W$. illuminata thus helps expand the morphological database for phylogenetic analysis of this group of digeneans and helps integrate morphological and molecular data into a better-supported phylogenetic hypothesis for the Microphalloidea. At the same time, it is important to note that some character interpretations change as a result of these new findings. For example, the most parsimonious interpretation of cercarial evolution in this group is that now the "virgulate" cercariae of the Lecithodendriidae are ancestral to the "ubiquita" cercariae of the Microphalloidae. In addition, a number of homoplasious evolutionary changes are required to maintain this hypothesis. Most noticeable is that the anterolateral movement of the genital pores likely occurred more than once within the Microphalloidea, e.g., in the common ancestor of the Leyogoniminae (Lecithodendriidae sensu stricto) and in $\mathrm{Ce}$ phalotrema and Coelomotrema, just as it has occurred convergently within other digenean groups. In addition, the initial hypothesis based solely on morphological data (summarized in Brooks and McLennan, 1993), the molecular hypothesis provided by Tkach et al. (2001), and the combined assessment presented herein all suggest that cecal length, adult body size, and distribution of vitelline follicles exhibit homoplasy within the Microphalloidea. For example, if the position of the members of the Prosthogonimidae is as depicted in Figure 4, all 3 of the putative synapomorphies for the Microphalloidea exhibit evolutionary reversals in the common ancestor of the family. The hypothesis that an entire suite of characters exhibits correlated evolutionary reversals requires a substantial amount of independent corroboration. Bearing in mind that the sequence database used by Tkach et al. (2001) produced a phylogenetic hypothesis with a consistency index of only $38 \%$, it is essential that we accumulate a much larger database of morphological characters for the microphalloids as well as sequence data for more species.

Adult prosthogonimids are typically parasitic in the oviduct and bursa Fabricii (of avian hosts), although P. ovatus may occur in the intestine (see Macy, 1934, 1935). Furthermore, Angel (1973) collected Cylindrotrema and Mawsonotrema in the cecum and liver, respectively. Whallwachsia illuminata was collected in the intestine of the hummingbird host and in the bile ducts of the passerine host. If $W$. illuminata is, like most parasites, a resource specialist (Brooks and McLennan, 1993, 2002; Adamson and Caira, 1994; Radtke et al., 2002), the key host resource for $W$. illuminata may be localized in different parts of the intestinal tract in the different hosts. Alternatively, these findings could reflect responses by the parasites to 2 related, but independent, variables, a physiological preference for bile salts, associated initially with metacercariae excystment and activation, as well as the need to track food in the host intestine to gain nutrition.

The yellow-olive flycatcher is a common resident of the lowelevation dry tropical forest throughout the year and is found in many microhabitats. We collected this species in xeric and riparian habitats in both wet and dry seasons, but the only record of W. illuminata we have was from a bird collected in June in the most xeric of microhabitats. Similarly, the steelyvented hummingbird is a common year-round resident, but unlike the previous species, is widely distributed throughout the ACG and found throughout a broad moisture gradient and elevation range. We collected this small hummingbird in diverse habitats ranging from xeric to riparian microhabitats in the dry tropical forest at elevations below $350 \mathrm{~m}$ elevation to wet humid montane rainforests above $600 \mathrm{~m}$ elevation. As with the flycatcher above, all but 1 of the $A$. saucerrottei infected with $W$. illuminata were obtained from the driest habitats in the dry tropical forest. The anomalous record was a hummingbird obtained from a meadow bordering the rainforest edge at Estacion San Gerardo. In other words, all records of $W$. illuminata are from birds collected at the beginning of the wet season (June) and, with 1 exception, from a xeric dry tropical forest microhabitat. Specimens collected at other times and from even adjacent microhabitats were not infected with W. illuminata.

Life-cycle studies for prosthogonimids have shown that the second intermediate host is an insect, as is the case for their probable sister groups. Yellow-olive flycatchers have broad flattened bills fringed with specialized bristles and are aerial predators of flying insects; in addition, they are known to glean insects, caterpillars, and beetles from limbs and foliage (Skutch, 1954, 1960, 1972, 1981; Stiles, 1983; Stiles and Skutch, 1989). Ingestion of an infected intermediate host seems inevitable given their bill morphology and feeding behaviors. Unlike fly- 
catchers, however, steely-vented hummingbirds have long narrow bills, which they use for extraction of nectar from tubular flowers, rarely for gleaning small spiders from foliage. Aerial predation is unknown (Skutch, 1972; Stiles and Skutch, 1989). The high prevalence of $W$. illuminata in this particular hummingbird is difficult to explain without a better understanding of the identity and ecology of the second intermediate host. Our data suggest that the second intermediate host, the one that directly infects the avian host, is restricted to the most xeric parts of the tropical dry forest, that it is emergent or more common at the beginning of the dry season, and that it is not captured in the air but more likely gleaned from vegetation. Furthermore, the data strongly indicate that the diet of steely-vented hummingbirds includes insects along with nectar and spiders, perhaps in far greater proportions than previously suspected.

\section{ACKNOWLEDGMENTS}

We are grateful to the scientific and technical staff of the ACG for support of this study, in particular to Elda Araya, Roger Blanco, Carolina Cano, Maria Marta Chavarría, Felipe Chavarría, Roberto Espinoza, Dunia Garcia, Guillermo Jimenez, Elba Lopez, Sigifredo Marin, Alejandro Masis, Calixto Moraga, Fredy Quesada, and Petrona Rios. We also thanks Dan Janzen and Winnie Hallwachs, scientific advisers to the ACG, for their support. Host specimens were collected by D.C., Jeremiah Trimble (Museum of Comparative Zoology [MCZ]), and $\mathrm{Ca}$ lixto Moraga (ACG) under the authority of CITES Permit US9258251, CITES Permit CR9123440, Costa Rica Ministero del Ambiente y Energia Licencia 203640283 and Resoluciones 215-2001-OFAU and 4112001-OFAU, Harvard University IACUC Protocol 21-09, and USDA APHIS Permit 47956 (Form VS16-6A). Host necropsy and parasite collections were made by D.R.B., D.C., Elda Araya, Sara Brant, Marie Causey, Ben Hanelt, Calixto Moraga, and Petrona Rios. This study was funded by a research grant from the Natural Sciences and Engineering Research Council (NSERC) of Canada to D.R.B. and by a grant from the MCZ Putnam Expedition Fund to D.C.

\section{LITERATURE CITED}

Adamson, M. L., AND J. N. CAIRA. 1994. Evolutionary factors influencing the nature of parasite specificity. Parasitology 109: S85S95.

Angel, L. M. 1973. The family Prosthogonimidae (Trematoda) in Australia. International Journal for Parasitology 3: 853-862.

BAER, J. G. 1943. Les trématodes parasites de la musaraigne d'eau Neomys fodiens (Schreb.). Bulletin de la Société Neuchâteloise des Science Naturelles 68: $33-84$.

Brooks, D. R. 2000. Parasite Systematics in the 21st Century: Opportunities and obstacles. Mémorias do Instituto Oswaldo Cruz 95: 99-109.

. 2003. Parasite systematics in the new age of discovery. Journal of Parasitology 89: 572-577.

- S. M. BANdoni, C. M. Macdonald, and R. T. O'Grady. 1989 Aspects of the phylogeny of the trematoda Rudolphi, 1808 (Platyhelminthes: Cercomeria). Canadian Journal of Zoology 67: 2609 2624

, AND E. P. Hoberg. 2000. Triage for the biosphere: The need and rationale for taxonomic inventories and phylogenetic studies of parasites. Comparative Parasitology 67: 1-25.

, AND —. 2001. Parasite systematics in the 21 st century: Opportunities and obstacles. Trends in Parasitology 17: 273-275.

- V. León-Régàgnon, And G. Pérez Ponce de León. 2000. Parasitos y la biodiversidad. In Enfoques contemporaneos para el estudio de la biodiversidad, M. H. Hernandez, A. N. Garcia, M. U1- loa, and N. F. Alvarez (eds.). UNAM, Mexico City, Mexico, p. 245-289.

- AND D. A. McLennan. 1993. Parascript: Parasites and the language of evolution. Smithsonian Institution Press, Washington, D.C., 429 p.

, AND 2002. The nature of diversity: An evolutionary voyage of discovery. University of Chicago Press, Chicago, Illinois, $668 \mathrm{p}$.

, R. T. O'Grady, AND D. R. GLen. 1985. Phylogenetic analysis of the Digenea (Platyhelminthes: Cercomeria) with comments on their adaptive radiation. Canadian Journal of Zoology 63: 411-443.

Hoberg, E. P. 2002. Foundations for an integrative parasitology: Collections, archives and biodiversity informatics. Comparative Parasitology 69: 124-131.

, S. J. Kutz, J. Cook, And K. E. Galbreath. 2003. Arctic biodiversity: From discovery to faunal baselines-Revealing the history of a dynamic ecosystem. Journal of Parasitology 89: 584-595.

Krasnolobova, T. A. 1969. Experimental proof of the synonymy of Prosthogonimus and Schistogonimus Lühe, 1909 (Trematoda: Prosthogonimidae). Trudy Gel'mintologicheskoi Laboratorii. Akademiya Nauk SSR 20: 79-87. [In Russian.]

LEÓN-RÉGÀGNON, V. 2003. Incorporating morphological and molecular data in biodiversity inventories: Parasites of leopard frogs. Journal of Parasitology 89: S141-S148.

, D. R. BROOKS, AND D. ZELMER. 2001. Morphological and molecular description of Haematoloechus meridionalis $\mathrm{n}$. sp. (Digenea: Plagiorchioidea: Haematoloechidae), in Rana vaillanti from Guanacaste, Costa Rica. Journal of Parasitology 87: 1423-1427.

MACY, R. W. 1934. Studies on the taxonomy, morphology, and biology of Prosthogonimus macrorchis Macy, a common oviduct fluke of domestic fowls in North America. University of Minnesota Agricultural Experiment Station Technical Bulletin 98: 7-71.

1935. On the life cycle of the trematode Prosthogonimus cuneatus (Rudolphi, 1809) (Plagiorchiidae) in Egypt. Transactions of the American Microscopical Society 84: 577-580.

PÉreZ-Ponce DE LEÓN, G. 2003. Biodiversity and biogeographic patterns in the Mesa Central of México: insights from host-parasite systems. Journal of Parasitology 89: S126-S133.

RadtKe, A., D. A. McLennan, And D. R. Brooks. 2002. Evolution of host specificity in Telorchis spp. (Digenea: Plagiorchiformes: Telorchiidae). Journal of Parasitology 88: 874-879.

Ramadan, M. M., M. F. A. SAOUd, AND A. H. Aly. 1988. A review of genus Prothogomius Lühe, 1899 (Prothogonimidae), from the Egyptian house sparrow: Passer domesticus niloticus. Journal of the Egyptian Society of Parasitology 18: 563-572.

SkUTCH, A. F. 1954. Life histories of Central American birds. Cooper Ornithological Society Pacific Coast Avifauna, no. 31. 448 pp.

. 1960. Life histories of Central American birds, II. Cooper Ornithological Society Pacific Coast Avifauna, no. 34. 593 pp.

1972. Studies of tropical American birds. Publications of the Nuttall Ornithology Club, no. 10. 228 pp.

- 1981. New studies of tropical American birds. Publications of the Nuttall Ornithology Club, no. 19. 281 pp.

Stiles, F. G. 1983. Birds. In Costa Rican natural history, D. H. Janzen (ed.). University of Chicago Press, Chicago, Illinois, p. 502-530. , AND A. F. SKutCH. 1989. A guide to the birds of Costa Rica. Cornell University Press, Ithaca, New York, 511 p.

TKach, V., J. Pawlowski, And J. Mariaux. 2000. Phylogenetic analysis of the suborder Plagiorchiata (Platyhelminthes, Digenea) based on partial lsrDNA sequences. International Journal for Parasitology 30: 83-93.

AND Z. SWIDERSK. 2001. Molecular phylogeny of the suborder Plagiorchiata and its position in the system of digenea. In Interrelationships of the platyhelminths, D. T. J. Littlewood and R. Bray (eds.). Taylor and Francis, London, U.K., p. 186-193.

YAMAGUTI, S. 1971. Synopsis of the digenetic trematodes of vertebrates. Keigaku Publishing Company, Tokyo, Japan, 1,074 p. 